\title{
Economic impact of Huanglongbing on orange production
}

\author{
Gustavo Vaz da Costa ${ }^{1}$, Carmen Silvia Vieira Janeiro Neves ${ }^{2}$, Renato Beozzo Bassanezi ${ }^{3}$, \\ Rui Pereira Leite Junior ${ }^{4}$, Tiago Santos Telles ${ }^{5}$ \\ Abstract - Huanglongbing (HLB) is considered one of the main citrus diseases; it spreads quickly \\ through orchards, reducing the production and quality of the fruit of affected plants, and causes \\ significant economic losses. In this context, the aim of this study was to estimate the incidence \\ and economic impact of the losses generated by HLB in the micro-region of Paranavaí, in the state \\ of Paraná, Brazil. We used data from the Paraná Agribusiness Defense Agency, which conducts \\ surveys of host plants of the causal agent of HLB. The production sacrificed by HLB was estimated \\ considering the following scenarios: (i) losses occurring from January 2011 to June 2013; and \\ (ii) losses related to the potential production of the citrus plant over its useful life. Although the \\ annual incidence of HLB in the Paranavaí region is currently below 2.5\%, there was a 6 -fold \\ increase in the incidence of the disease, from $0.16 \%$ to $0.96 \%$, in the period considered. Orchards \\ that had lesser than 10,000 plants showed a higher incidence of the disease. The losses produced \\ by HLB generated estimated economic impacts of US\$11.8 million and US $\$ 39.2$ million for the \\ first and second scenarios, respectively. These results highlight the importance of the prevention \\ and management of this disease.
}

Index terms: citrus; HLB; greening; production sacrificed; economic valuation.

\section{Impacto econômico do Huanglongbing na produção de laranja}

Corresponding author: telles@idr.pr.gov.br

Received: October 20, 2020 Accepted: February 18, 2021

Copyright: All the contents of this journal, except where otherwise noted, is licensed under a Creative Commons Attribution License.

\section{(cc) $\mathbf{E Y}$}

Resumo - O Huanglongbing (HLB) é considerado uma das principais doenças da citricultura, disseminando-se rapidamente pelos pomares, reduzindo a produção e a qualidade das frutas das plantas afetadas, com perdas econômicas significativas. Neste contexto, com este estudo, objetivouse estimar a incidência e o impacto econômico das perdas geradas pelo HLB na microrregião de Paranavaí, no Estado do Paraná. Foram utilizados dados do relatório de vistorias de plantas hospedeiras do agente causal do HLB, da Agência de Defesa Agropecuária do Paraná. Foi aplicada a metodologia da produção sacrificada, considerando os seguintes cenários: (i) perdas que ocorrem no período de janeiro de 2011 a junho de 2013; e (ii) perdas em função do potencial de produção da planta de citros ao longo de sua vida útil. Embora a incidência anual de HLB, na região de Paranavaí, esteja abaixo de $2,5 \%$, houve aumento de 6 vezes na incidência da doença, que passou de $0,16 \%$ para $0,96 \%$, no período. Pomares com menos de 10 mil plantas apresentaram maior incidência da doença. As perdas ocasionadas pelo HLB geraram impacto econômico estimado em US\$11,8 milhões, para o primeiro cenário, e em US\$ 39,2 milhões, para o segundo cenário. Estes resultados evidenciam a importância da prevenção e do manejo da doença.

Termos para indexação: citricultura; HLB; greening; produção sacrificada; valoração econômica.

\footnotetext{
${ }^{1}$ Economist, M.Sc., Universidade Estadual de Londrina. Londrina-PR, Brazil. E-mail: gustavo.vaz.costa@gmail.com ${ }^{(0 R C I D: 0000-0002-1115-3892)}$ ${ }^{2}$ Agronomist, Ph.D., Professor at the Universidade Estadual de Londrina. Londrina-PR, Brazil. Email: csvjneve@uel.br (ORCID: 0000-0001-9000-167X) ${ }^{3}$ Agronomist, Ph.D., Researcher at the Fundecitrus. Araraquara-SP, Brazil. E-mail: renato.bassanezi@fundecitrus.com.br ${ }^{\text {(ORCID: 0000-0003-4973-6708) }}$ ${ }^{4}$ Agronomist, Ph.D., Researcher at the Instituto de Desenvolvimento Rural do Paraná. Londrina-PR, Brazil. E-mail: ruileite@idr.pr.gov.br (ORCID: 0000-0001-8211-7840)

${ }^{5}$ Economist, Ph.D., Researcher at the Instituto de Desenvolvimento Rural do Paraná. Londrina-PR, Brazil. E-mail: telles@idr.pr.gov.br ${ }^{(0 R c I D}$ 0000-0001-5817-3420)
} 


\section{Introduction}

Huanglongbing (HLB) or greening is one of the main citrus diseases in the world. Despite being identified over a century ago in Southeast Asia (BOVÉ, 2006), a viable cure has not been applied on a commercial scale. The lack of a cure linked to the high dissemination rate has resulted in economic losses due to the damage caused by HLB. However, there have been few studies to estimate the losses resulting from HLB, especially in Brazil. In the state of Florida, in the USA, these losses were estimated at approximately US $\$ 1$ billion per year (LI et al., 2020). In the state of Bahia, the incidence of HLB would generate losses greater than R $\$ 1.8$ billion (OLIVEIRA et al., 2013).

HLB is caused by a gram-negative, uncultivable bacterium, Candidatus Liberibacter asiaticus, which colonizes the phloem, and is naturally transmitted by vector insects, such as the Asian citrus psyllid, Diaphorina citri. This bacterium is difficult to control, and is classified as a quarantine pest at national and international levels; in Brazil, it is mandatory to eliminate its inoculum sources. There is a substantial amount of agronomic, phyto-pathological, and geographical information on HLB (BLAUSTEIN et al., 2018; GASPAROTO et al., 2018; MUNIR et al., 2018), evidencing its damage potential. However, there have been few studies on the economic impact generated by the losses resulting from HLB (OLIVEIRA et al., 2013; SPREEN et al., 2014; ALVAREZ et al., 2016; LI et al., 2020), and no such studies have been conducted for the state of Paraná.

In 2019, Paraná was the fourth largest orange producer of Brazil (IBGE, 2020). An expansion in the production of this fruit in the Paraná territory occurred during the 1990s, owing to the implementation of integrated management for the prevention of citrus canker, guided by the Agricultural Research Institute of Paraná State - IAPAR (TAZIMA et al., 2009). Since then, there has been a great advance in orange production. Between 2001 and 2019, the production increased from 302,000 tons, in a cultivated area of approximately 14,000 hectares, to 694,000 tons, in a cultivated area of approximately 21,000 hectares (IBGE, 2020). This expansion made orange the main product of Paraná fruticulture.

Despite the advances in orange production in Paraná, the citrus sector faces serious phytosanitary problems owing to HLB. HLB was first reported in Paraná in 2006, in the municipality of Altônia, and it spread through the North and Northwest regions (NUNES et al., 2010). The Northwest region is the most important in the Paraná citrus chain (COSTA et al., 2020); it accounts for, on average, $66 \%$ of the state's orange production, $56 \%$ of the cultivated area, and $57 \%$ of the gross fruit production value (IBGE, 2020). Hence, the evaluation of the losses caused by HLB to the Northeast citrus region is of great importance, especially for the planning and sustainability of the citrus production chain in Paraná.
Therefore, in this study, we aimed to estimate the incidence of HLB and the economic losses it generated during orange production in the Paranavaí micro-region, Northwest of the state of Paraná.

\section{Materials and methods}

To estimate losses generated by HLB, the "Semiannual reports of host plants of the Huanglongbing causal agent (HLB) or greening - inspection by the owner," made available by the Paraná Agribusiness Defense Agency ADAPAR), were used. These reports are mandatory, and are completed and delivered every six months by orange producers. Moreover, the farmers are responsible for the surveys and possible eradication of the symptomatic HLB plants, under penalty in the case of non-execution. The procedures were established via Normative Instruction No. 53 of October 16, 2008, of the Ministry of Agriculture, Livestock and Supply (MAPA).

These reports were chosen because they contain information regarding the producer and his property, including the variety of citrus planted as well as the planting date, number of plants inspected, and the number of symptomatic HLB plants eradicated. The Paranavaí micro-region reports from January 2011 to June 2013 were analyzed.

To calculate the economic losses generated by HLB, it was considered that all plants eradicated by the producers presented disease symptoms. These plants constituted the orange production sacrificed due to HLB. In this context, it was considered that every symptomatic HLB plant that was eradicated generated an equivalent cost to the orange production capacity according to the plant age and income that ceased to be generated.

For the model, the regional condition, orchard location (Paranavaí micro-region), and eradicated plant age were considered. To determine the productivity variable or production capacity $(Q)$ with respect to plant age, the average productivity of the plants, based on long-term experiments of the IAPAR, was adopted, as presented in Figure 1. 


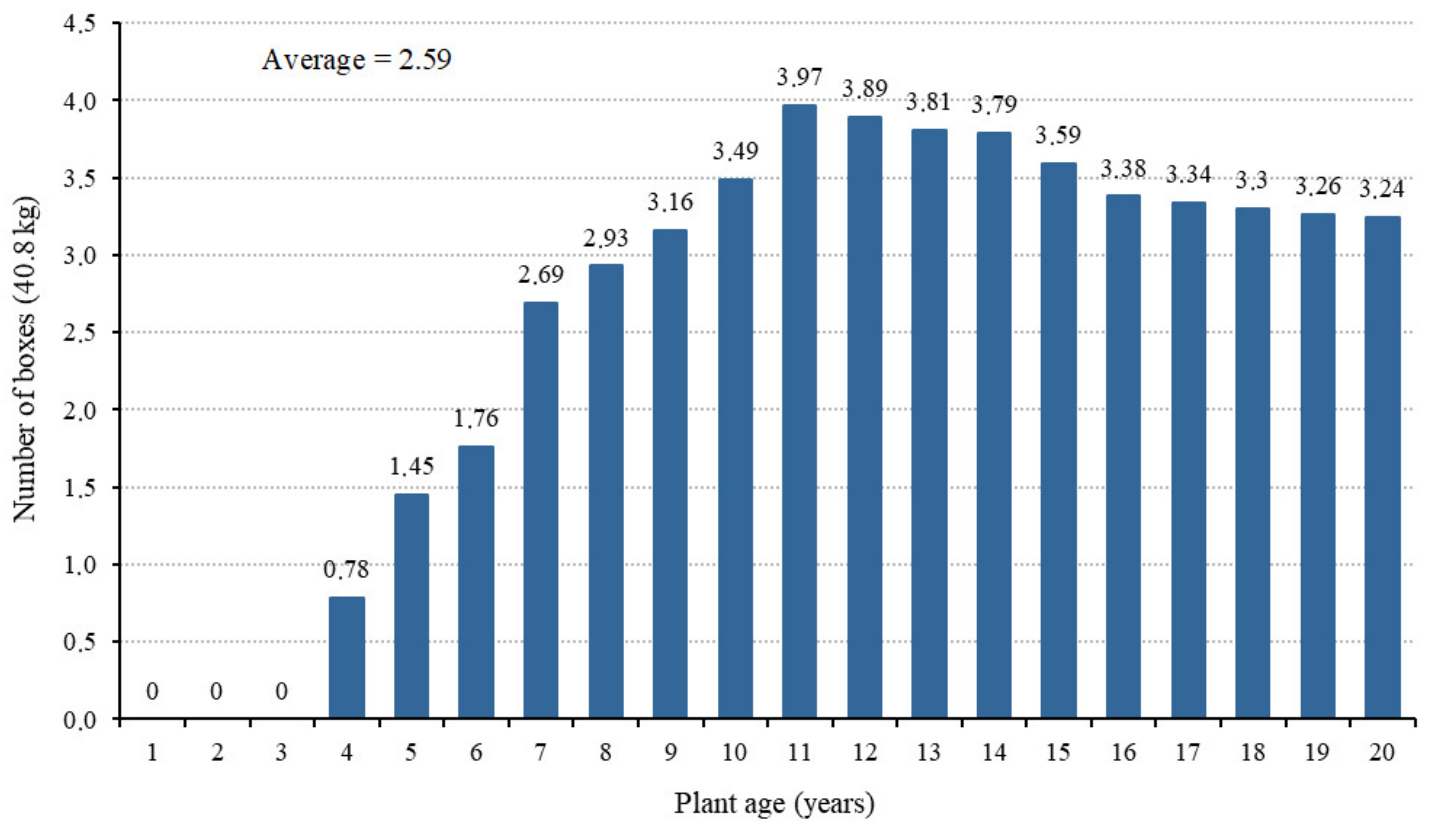

Figure 1. Average orange plant productivity in boxes $(40.8 \mathrm{~kg}$ ), based on plant age (years), for the state of Paraná. Elaborated based on experimental data from the Agricultural Research Institute of Paraná State - IAPAR.

The economic impact was calculated based on the production sacrificed by HLB (PS), which is the orange production loss due to HLB, considering two scenarios: (i) losses resulting from PS in the calculation period (Equation 1), considering the production capacity of the year in which the plant was eradicated; and (ii) accumulated losses, taking into account, in addition to PS in the calculation period, that resulting from citrus plant production potential throughout its useful life (Equation 2).

Equation 1

$$
P S_{j}=\sum_{i=0}^{3} Q_{i} C_{i}+\sum_{i=0}^{20} Q_{i} C_{i} p_{j}+Q_{(20+)} P_{20} p_{j}+Q_{(S I)} \bar{P} p_{j}
$$

Equation 2

$$
\begin{aligned}
P S_{j}=\sum_{i=0}^{1} Q_{i} C_{i+2}+\sum_{i=0}^{2} Q_{i} C_{i+1}+\sum_{i=0}^{3} Q_{i} C_{i}+\sum_{i=4}^{20} Q_{i} P_{i} p_{j}+\sum_{i=3}^{19} Q_{i} P_{i+1} p_{j} \\
+\sum_{i=2}^{18} Q_{i} P_{i+2} p_{j}+Q_{19} P_{20} p_{j}+2 Q_{20} P_{20} p_{j}+3 Q_{(20+)} P_{20} p_{j} \\
+Q_{(S l)} \bar{P} p_{j}
\end{aligned}
$$

Where $P S_{j}$ is the production sacrificed due to HLB in year $j$, in orange boxes of $40.8 \mathrm{~kg}$; $Q$ is the total quantity of eradicated plants; $Q_{(20+)}$ is the total eradicated quantity of plants over 20 years of age; and $Q$ is the total quantity of plants eradicated without age identification (WI). In the case of WI plants, the average plant production $(P)$ throughout their useful life, in orange boxes of $40.8 \mathrm{~kg}$, was used. $C$ is the planting and plant maintenance cost until the third year of age (non-productive phase). $P$ is the production capacity per plant, in orange boxes of $40.8 \mathrm{~kg}$, which varies with the plant age, with intervals between 1 and 20 years. For plants over 20 years of age, the production of a 20 -year-old plant was considered. $P$ is the orange box price of $40.8 \mathrm{~kg}$ for the year $j$, and $i$ is the plant age.

To calculate the HLB economic impact, the following periods were considered: $J_{1}$, referring to the year $2011 ; J_{2}$, referring to the year 2012 ; and $J_{3}$, referring to the year 2013. The possibility of replanting eradicated plants was not considered in the analysis.

The nominal values were updated to real values of December 2019, based on the Ample Consumer Price Index (IPCA), of the IBGE. The real values were converted into dollars, considering the December 2019 exchange rate. SPSS 21 software was used for data processing.

\section{Results and Discussion}

In the study of the economic impact caused by HLB disease in the citrus crop of the Paranavaí micro-region, 21,781 buttons were analyzed, and inspection reports of 2,086 orchards from January 2011 to June 2013, provided by ADAPAR, were included. In this period, there was an increase in the number of orange plants inspected, and correspondingly, an increase in the number of plants eradicated due to the incidence of HLB (Table 1). The increase in the proportion of eradicated plants was due to the increase in the percentage of sick plants, which was less than $0.16 \%$ in $2011,0.32 \%$ in 2012 , and $0.96 \%$ in 2013 (Table 1), indicating that the recommended control measures were not being adopted by all the producers or that they were not sufficient to contain the HLB epidemic advance. 
Table 1. Number of producers, plants inspected, plants eradicated, and average Huanglongbing (HLB) incidence, based on agricultural property size, in Paranavaí micro-region, state of Paraná, in the period from January 2011 to June 2013.

\begin{tabular}{|c|c|c|c|c|}
\hline Property size & Producers inspected & Plants inspected & Plants eradicated & HLB incidence \\
\hline \multicolumn{5}{|c|}{2011} \\
\hline$\leq 10 \mathrm{~K}$ plants & 26 & 129,579 & 1,056 & $0.81 \%$ \\
\hline$>10 \mathrm{~K}$ to $100 \mathrm{~K}$ plants & 85 & $2,261,959$ & 3,445 & $0.15 \%$ \\
\hline$>100 \mathrm{~K}$ to $500 \mathrm{~K}$ plants & 15 & $2,268,541$ & 2,728 & $0.12 \%$ \\
\hline$>500 \mathrm{~K}$ plants & - & - & - & - \\
\hline Total & 126 & $4,660,079$ & 7,229 & $0.16 \%$ \\
\hline \multicolumn{5}{|c|}{2012} \\
\hline$\leq 10 \mathrm{~K}$ plants & 33 & 134,779 & 1,505 & $1.12 \%$ \\
\hline$>10 \mathrm{~K}$ to $100 \mathrm{~K}$ plants & 80 & $1,993,729$ & 7,766 & $0.39 \%$ \\
\hline$>100 \mathrm{~K}$ to $500 \mathrm{~K}$ plants & 7 & $1,061,729$ & 2,337 & $0.22 \%$ \\
\hline$\geq 500 \mathrm{~K}$ plants & 2 & $1,842,039$ & 4,332 & $0.24 \%$ \\
\hline Total & 122 & $5,032,276$ & 15,940 & $0.32 \%$ \\
\hline \multicolumn{5}{|c|}{2013} \\
\hline$\leq 10 \mathrm{~K}$ plants & 44 & 149,314 & 3,511 & $2.35 \%$ \\
\hline$>10 \mathrm{~K}$ to $100 \mathrm{~K}$ plants & 82 & $2,345,078$ & 33,005 & $1.41 \%$ \\
\hline$>100 \mathrm{~K}$ to $500 \mathrm{~K}$ plants & 14 & $2,216,113$ & 16,071 & $0.73 \%$ \\
\hline$>500 \mathrm{~K}$ plants & 1 & $2,312,873$ & 14,775 & $0.64 \%$ \\
\hline Total & 141 & $7,023,378$ & 67,362 & $0.96 \%$ \\
\hline
\end{tabular}

Considering that the disease was first reported in Paraná in 2007, three years after the first report in the state of São Paulo, the HLB incidence in the Paranavaí microregion was lower than that observed in the São Paulo citrus belt and Southeast of the Mineiro Triangle (CCSPTSM), that is, $0.61 \%$ in $2008,0.89 \%$ in $2009,1.89 \%$ in 2010 , $3.80 \%$ in 2011 , and $6.95 \%$ in 2012 (BASSANEZI et al., 2020). However, the annual HLB incidence progress rate, obtained using the Gompertz model (GASPAROTO et al., $2018)$, for the Paranavaí micro-region $(r=0.163)$, was similar to the observed rate for the CCSPTSM $(r=0.166)$.

Approximately $90 \%$ of the orange producers in the Paranavaí region own properties with less than 100,000 plants. However, producers owning properties with more than 100,000 plants represent $10 \%$ of the total, and control more than half of the total orange production of the region (Table 1). For every year, the HLB incidence was inversely proportional to the property size, and properties with up to 10,000 plants presented the highest incidences, whereas properties with more than 500,000 plants presented the lowest (Table 1). This situation was similar to that observed for the CCSPTSM, where the number of orange trees with HLB symptoms was higher in small and medium-sized properties (BASSANEZI et al., 2020). The reasons for such occurrences are disinformation, low technology use by small producers, and the difficulty of controlling primary disease infections, which are derived from infectious psyllids from areas near the property, despite insecticide applications during the emission period of new citrus plant buds (BASSANEZI et al., 2013a; BERGAMIN FILHO et al., 2016) - the preferred sites for psyllids to feed, reproduce, and consequently, transmit HLB bacteria (HALL et al., 2016; CIFUENTES-ARENAS et al., 2018).

The difficulty in controlling infectious psyllids, even with insecticide applications during the emission period of buds in citrus plants, arises from the growth of the buds, which exposes new tissues that were not covered by the contact insecticides, and the washing off of the insecticides during rainy periods, which reduces the residual control period (CARLI, 2018).

In addition, owing to the psyllid dispersion behavior (BOINA et al., 2009; SÉTAMOU; BERTELS, 2015), the primary infections are generally concentrated in the first 100 to $200 \mathrm{~m}$ of the orchard from its periphery, called the edge range (BASSANEZI et al., 2005; GASPAROTO et al., 2018), regardless of the property size. For properties that cover hundreds of hectares, the edge range area represents a small proportion of the total property area. In small properties, with only a few dozen hectares, the total area occupied by the edge range is higher, leaving them more exposed to primary infections (BASSANEZI et al., 2013a; 2013b).

The increase in the HLB incidence in the Paranavai micro-region occurred in orchards of all age classes (Table 2). In 2013, the highest incidences were observed in orchards of 6 to 10 years of age, which contained $1.14 \%$ of the symptomatic plants, followed by orchards of 3 to 5 years of age, those over 10 years of age, and orchards of 0 to 2 years of age (Table 2). The lowest incidence of HLB in orchards of 0 to 2 years of age was observed in the CCSPTSM (BASSANEZI et al., 2020). 
Table 2. Number of plants inspected and eradicated, and average Huanglongbing incidence (HLB), based on age group, in the period from January 2011 to June 2013.

\begin{tabular}{lccc}
\hline \multicolumn{1}{c}{ Age Group } & Plants inspected & Plants eradicated & HLB incidence \\
\hline \multicolumn{3}{c}{2011} \\
WI ${ }^{(1)}$ & 458,742 & 889 & \\
0 to 2 years & 241,254 & 64 & $0.19 \%$ \\
3 to 5 years & $1,353,885$ & 1,783 & $0.03 \%$ \\
6 to 10 years & $1,816,061$ & 3,654 & $0.13 \%$ \\
over 10 years & 790,138 & 839 & $0.20 \%$ \\
Total & $4,660,079$ & 7,229 & $0.11 \%$ \\
\hline & & & $0.16 \%$ \\
WI & - & - & \\
0 to 2 years & 2012 & 536 & - \\
3 to 5 years & $1,535,262$ & 5,548 & $0.26 \%$ \\
6 to 10 years & $2,248,690$ & 7,435 & $0.36 \%$ \\
over 10 years & $1,039,317$ & 2,421 & $0.33 \%$ \\
Total & $5,032,275$ & 15,940 & $0.23 \%$ \\
& & & $0.32 \%$ \\
WI & 2013 & 3,429 & $0.61 \%$ \\
0 to 2 years & 564,752 & 689 & $0.23 \%$ \\
3 to 5 years & 293,705 & 10,179 & $0.91 \%$ \\
6 to 10 years & $1,118,456$ & 38,678 & $1.14 \%$ \\
over 10 years & $3,405,579$ & 14,387 & $0.88 \%$ \\
Total & $1,640,885$ & 67,362 & $0.96 \%$ \\
\hline
\end{tabular}

Note: ${ }^{(1)}$ Refers to plants without age identification, and is considered the average productivity.

Orchards under 2 years of age, with frequent emissions of new buds, are more susceptible to bacterium transmission by psyllids, and are therefore more frequently treated with contact insecticides and systemic applications. For plants in production (over 2 years), systemic insecticide applications are more expensive (need higher product doses) and do not work well for psyllid control; hence, they are no longer being performed by producers. Significant increases in disease transmission are common in orchards in the years following the stoppage of systemic insecticide use. In addition, young plants in training that are contaminated by the HLB bacterium quickly deteriorate and lose their productive capacity, and can be removed and replaced by healthy seedlings; this substitution is better accepted by citrus producers.

Older plants in production that are infected by the HLB bacterium take a few years to deteriorate and have their productive capacity compromised (BASSANEZI, 2018); moreover, they are more expensive to remove, and depending on the orchard age, cannot always be replaced by new seedlings. Hence, citrus producers rarely accept the elimination of adult plants contaminated by HLB, which are still productive, and generally delay their elimination, even without the normative instruction (BELASQUE JUNIOR et al., 2010a; BASSANEZI et al., 2020).

Disease incidence progress is an important factor that should be monitored, because in 3 to 13 years after the emergence of the first plants with symptoms, the incidence can increase to 95\% in the area (GOTTWALD et al., 2007). In the State of São Paulo, HLB was first identified in 2004, and in 2009, it was present in $24 \%$ of commercial orchards (BELASQUE JUNIOR et al., 2010a). This rapid increase in the disease incidence in orchards and the symptom severity in infected plants reduced the production and quality of the fruits, making an orchard economically unfeasible in about 7 to 10 years after planting (BASSANEZI et al., 2010).

In Florida, in the USA, HLB was first identified in 2005, and in 9 years from the first incidence, the citrus planting area decreased by approximately $20 \%$, from 251,461 to 202,908 hectares in 2014 (SPREEN; ZANSLER, 2016). The total orange production in the $2015 / 16$ crop, which was 81.7 million boxes, was approximately one third of the production in 2004/05, the year before the discovery of HLB in the region (TREJO-PECH et al., 2018). It has been estimated that at least $80 \%$ of citrus plants in Florida are affected by the disease (SINGERMAN; USECHE, 2017). The disease emergence has resulted in billing reductions, increases in the orchard maintenance costs, and an increase in production uncertainty, making the activity less attractive for the producers, and causing a significant drop in orange fruit production (SPREEN; ZANSLER, 2016).

The presence of HLB increases the production costs owing to the need for disease management, which is based on its prevention. The following practices are recommended for this: (i) acquiring healthy seedlings from 
certified nurseries, (ii) maintaining psyllid populations at the lowest possible levels, with frequent chemical and biological insecticide applications, (iii) frequent orchard inspections, and (iv) eradication of infected plants (BELASQUE JUNIOR et al., 2010b; 2010c). This has been the best strategy for the prevention and containment of HLB, although it is not a definitive disease control (MONZO; STANSLY, 2017). The eradication of symptomatic plants for inoculum reduction has been recommended worldwide for disease control (BOVÉ, 2006). In Brazil, this is the official management guideline established by normative instruction No. 53, of October 16, 2008, of MAPA.
The economic impact generated by HLB in the first scenario was great loss related to plants of 5 to 11 years of age (Table 3); the orange plant productivity in Paraná was at its peak 11 years after planting (Figure 1). It is notable that the cost of the sacrificed plants refers to the orange plant formation cost, since plants less than three years of age do not produce fruits. From the fourth year, the eradication started to generate an economic impact based on the plant productivity. The orchard class of 6 to 10 years exhibited the highest number of diseased plants in 2011 and 2013 (Table 2).

Table 3. Economic impact of losses caused by Huanglongbing (HLB) based on agricultural year and citrus plant age, considering the productive capacity of the year in which it was eradicated (scenario 1), in Paranavaí micro-region, state of Paraná, in the period from January 2011 to June 2013.

\begin{tabular}{|c|c|c|c|c|}
\hline \multirow{2}{*}{ Plant age } & \multicolumn{3}{|c|}{ Year } & \multirow{2}{*}{ Total } \\
\hline & 2011 & 2012 & 2013 & \\
\hline Years & \multicolumn{4}{|c|}{ Losses (US\$) ${ }^{(1)}$} \\
\hline 1 & 576.08 & 0.00 & $14,833.35$ & $15,409.43$ \\
\hline 2 & $3,706.23$ & $33,108.83$ & $36,197.35$ & $73,012.41$ \\
\hline 3 & $46,908.73$ & $63,504.63$ & $60,710.40$ & $171,123.75$ \\
\hline 4 & $53,511.84$ & $54,075.29$ & $36,719.63$ & $144,306.76$ \\
\hline 5 & $82,183.22$ & $186,057.03$ & $518,906.54$ & $787,146.80$ \\
\hline 6 & $80,556.27$ & $63,219.21$ & $854,606.97$ & $998,382.45$ \\
\hline 7 & $378,143.69$ & $55,958.22$ & $815,418.39$ & $1,249,520.30$ \\
\hline 8 & $217,738.63$ & $368,239.07$ & $503,709.85$ & $1,089,687.55$ \\
\hline 9 & $257,701.75$ & $225,843.00$ & $1,199,423.95$ & $1,682,968.70$ \\
\hline 10 & $105,662.82$ & $182,865.82$ & $1,099,742.99$ & $1,388,271.63$ \\
\hline 11 & $81,344.26$ & $74,571.95$ & $689,976.76$ & $845,892.97$ \\
\hline 12 & $12,689.35$ & $11,537.24$ & $225,579.63$ & $249,806.22$ \\
\hline 13 & $21,361.32$ & $6,277.78$ & $121,965.65$ & $149,604.74$ \\
\hline 14 & $19,317.45$ & $22,793.56$ & $62,609.11$ & $104,720.12$ \\
\hline 15 & $16,468.26$ & $7,541.96$ & $63,299.85$ & $87,310.07$ \\
\hline 16 & $9,992.06$ & $14,897.73$ & $10,415.02$ & $35,304.81$ \\
\hline 17 & $11,235.69$ & $1,788.58$ & $66,038.82$ & $79,063.10$ \\
\hline 18 & $31,621.45$ & $108,884.60$ & $43,922.34$ & $184,428.39$ \\
\hline 19 & $16,283.72$ & $8,191.58$ & $435,154.99$ & $459,630.30$ \\
\hline 20 & $38,643.03$ & $28,160.95$ & $23,849.76$ & $90,653.74$ \\
\hline $20+(2)$ & $337,878.81$ & $61,793.97$ & $931,528.14$ & $1,331,200.92$ \\
\hline $\mathrm{WI}^{(3)}$ & $234,851.45$ & 0.00 & $380,302.92$ & $615,154.37$ \\
\hline Total & $2,058,376.10$ & $1,579,311.00$ & $8,194,912.43$ & $11,832,599.53$ \\
\hline
\end{tabular}

Notes: ${ }^{(1)}$ Real values of December 2019. (2) Refers to plants over 20 years of age, and is considered the productivity of a 20 -year-old plant.

(3) Refers to plants without age identification, and is considered the average productivity. 
In the second scenario, the plant production capacity was considered throughout its useful life (Table 4). In this situation, the impact of eradicating a 1-year-old a plant extends to the third year of production. Unlike in the first scenario, plants under three years of age generate losses related to the deployment cost and production capacity alone, because these plants start producing fruits only in the fourth year. In this scenario, it was more evident that the losses were related to plants between 5 and 11 years of age, and not older, and the cost generated by HLB in orange production was estimated to be almost US\$15.7 million per year.

Table 4. Economic impact of losses caused by Huanglongbing (HLB) based on plant age, considering the orange plant production capacity throughout its useful life (scenario 2), in Paranavaí micro-region, state of Paraná, in the period from January 2011 to June 2013.

\begin{tabular}{|c|c|c|c|c|}
\hline \multirow{2}{*}{ Plant age } & \multicolumn{3}{|c|}{ Year } & \multirow{2}{*}{ Total } \\
\hline & 2011 & 2012 & 2013 & \\
\hline Years & \multicolumn{4}{|c|}{ Losses US\$ ${ }^{(1)}$} \\
\hline 1 & 576.08 & 0.00 & $14,833.35$ & $31,078.80$ \\
\hline 2 & $3,706.23$ & $33,108.83$ & $36,197.35$ & $214,649.81$ \\
\hline 3 & $46,908.73$ & $63,504.63$ & $60,710.40$ & $434,384.17$ \\
\hline 4 & $53,511.84$ & $54,075.29$ & $36,719.63$ & $738,184.56$ \\
\hline 5 & $82,183.22$ & $186,057.03$ & $518,906.54$ & $3,202,873.13$ \\
\hline 6 & $80,556.27$ & $63,219.21$ & $854,606.97$ & $4,186,399.14$ \\
\hline 7 & $378,143.69$ & $55,958.22$ & $815,418.39$ & $4,078,359.82$ \\
\hline 8 & $217,738.63$ & $368,239.07$ & $503,709.85$ & $3,562,869.07$ \\
\hline 9 & $257,701.75$ & $225,843.00$ & $1,199,423.95$ & $5,656,052.99$ \\
\hline 10 & $105,662.82$ & $182,865.82$ & $1,099,742.99$ & $4,514,866.25$ \\
\hline 11 & $81,344.26$ & $74,571.95$ & $689,976.76$ & $2,486,541.77$ \\
\hline 12 & $12,689.35$ & $11,537.24$ & $225,579.63$ & $737,859.54$ \\
\hline 13 & $21,361.32$ & $6,277.78$ & $121,965.65$ & $439,390.30$ \\
\hline 14 & $19,317.45$ & $22,793.56$ & $62,609.11$ & $297,305.59$ \\
\hline 15 & $16,468.26$ & $7,541.96$ & $63,299.85$ & $250,742.82$ \\
\hline 16 & $9,992.06$ & $14,897.73$ & $10,415.02$ & $104,661.06$ \\
\hline 17 & $11,235.69$ & $1,788.58$ & $66,038.82$ & $234,348.84$ \\
\hline 18 & $31,621.45$ & $108,884.60$ & $43,922.34$ & $547,696.49$ \\
\hline 19 & $16,283.72$ & $8,191.58$ & $435,154.99$ & $1,373,251.22$ \\
\hline 20 & $38,643.03$ & $28,160.95$ & $23,849.76$ & $271,961.32$ \\
\hline $20+(2)$ & $337,878.81$ & $61,793.97$ & $931,528.14$ & $3,993,602.75$ \\
\hline $\mathrm{WI}^{(3)}$ & $234,851.45$ & 0.00 & $380,302.92$ & $1,845,463.20$ \\
\hline Total & $6,770,428.10$ & $5,292,492.64$ & $27,139,621.91$ & $39,202,542.65$ \\
\hline
\end{tabular}

Notes: ${ }^{(1)}$ Real values of December 2019. ${ }^{(2)}$ Refers to plants over 20 years of age, and is considered the productivity of a 20 -year-old plant. ${ }^{(3)}$ Refers to plants without age identification, and is considered the average productivity.

It is notable that, despite the cost of an inspection being lower than the cost of applying insecticides for psyllid control, most producers perform management for vector control, and regardless of the validity of normative instruction No. 53, of October 16, 2008, of MAPA, some producers do not eradicate infected plants (BELASQUE JUNIOR et al., 2010b; 2010c). Furthermore, the eradication of all symptomatic plants will not necessarily result in the eradication of all infected plants, because asymptomatic plants can exist (GOTTWALD, 2010). In addition, there is a direct and immediate loss when a symptomatic but productive plant is eradicated, especially adult plants with initial disease symptoms, that is, plants that would be productive for some more years (BASSANEZI et al., 2013b).
The eradication of diseased plants is a strategy used when the HLB incidence is low; however, it becomes unfeasible when there are many infected plants, as in the case of Florida, USA (FARNSWORTH et al., 2014; TANSEY et al., 2017). In both Florida and Brazil, other measures, such as increasing the planting density, have been used; they contributed significantly to an increase in income per unit area (TREJO-PECH et al., 2018). In addition, the American industry tried to adopt other approaches for damage mitigation, based on the assumption that it would be possible to produce under disease conditions, through insecticide applications for psyllid control and implementation of a nutritional program with the use of leaf macro and micronutrients, 
to reduce the plant stress caused by the disease and help maintain productivity (STANSLY et al., 2014). However, this strategy significantly increased the production costs (LI et al., 2020).

Although the economic loss estimated in this study specifically concerns on farm losses, HLB negatively impacts all links of the orange production chain. In addition, since the infestation indices are increasing, it is believed that the economic losses will increase. Therefore, to avoid such increases in losses and maintain citrus crop production as an economically viable activity, it is of great importance to rigorously adopt the recommended measures for disease control, as well as increase the awareness of rural producers.

\section{Conclusions}

The incidence of HLB increased from $0.16 \%$ to $0.96 \%$ in the Paranavaí micro-region, in the state of Paraná, Brazil between January 2011 and June 2013. The highest incidence of HLB was in orchards with less than 10,000 plants.

The economic loss due to HLB for the Paranavai micro-region, without considering the plant production potential, was approximately US $\$ 4.7$ million per year, and considering the plant production potential, was US\$15.7 million per year.

\section{References}

ALVAREZ, S.; ROHRIG, E.; SOLÍS, D.; THOMAS, M.H. Citrus greening disease (Huanglongbing) in Florida: economic impact, management and the potential for biological control. Agricultural Research, New Delhi, v.5, n.2, p.109-118, 2016.

BASSANEZI, R.B.; LOPES, S.A.; MIRANDA, M.P.; WULFF, N.A.; VOLPE, H.X.L.; AYRES, A.J. Overview of citrus Huanglongbing spread and management strategies in Brazil. Tropical Plant Pathology, Brasília, DF, v.45, p.251-264, 2020.

BASSANEZI, R.B. Evolución de la severidad y el daño de Huanglongbing en plantaciones de naranjo dulce y sus implicaciones para el manejo de la enfermedad. Cítricos en las Américas, v.1, n.1, p.31-44, 2018.

BASSANEZI, R.B.; MONTESINO, L.H.; GIMENESFERNANDES, N.; YAMAMOTO, p.T.; GOTTWALD, T. R.; AMORIM, L.; BERGAMIN FILHO, A. Efficacy of area-wide inoculum reduction and vector control on temporal progress of Huanglongbing in young sweet orange plantings. Plant Disease, Saint Paul, v.97, p.789796, 2013a.
BASSANEZI, R.B.; BELASQUE JUNIOR, J.; MONTESINO, L.H. Frequency of symptomatic trees removal in small citrus blocks on citrus huanglongbing epidemics. Crop Protection, Edmonton, v.52, p.72-77, 2013b.

BASSANEZI, R.B.; LOPES, S.A.; BELASQUE JUNIOR, J.; SPOSITO, M.B.; YAMAMOTO, P.T.; MIRANDA, M.P.; TEIXEIRA, D.C.; WULFF, N.A. Epidemiologia do Huanglongbing e suas implicações para o manejo da doença. Citrus Research \& Technology, Cordeirópolis, v.31, n.1, p.11-23, 2010.

BASSANEZI, R.B.; BUSATO, L.A.; SANCHES, A.L.; BARBOSA, J.C. Danos da morte súbita dos citros sobre a produção de laranja. Fitopatologia Brasileira, Brasília, DF, v.30, n.5, p.497-503, 2005.

BELASQUE JUNIOR, J.; BARBOSA, J.C.; MASSARI, C.A.; AYRES, A.J. Incidência e distribuição do Huanglongbing no estado de São Paulo, Brasil. Citrus Research \& Technology, Cordeirópolis, v.31, n.1, p.1-9, 2010a.

BELASQUE JUNIOR, J.; BASSANEZI, R.B.; YAMAMOTO, P.T.; AYRES, A.J.; TACHIBANA, A.;VIOLANTE, A.R.; TANK JUNIOR., A.; DI GIORGI, F.; TERSI, F.E.A.; MENEZES, G.M.; DRAGONE, J.; JANK JUNIOR, R.H.; BOVÉ, J.M. Lessons from huanglongbing management in São Paulo State, Brazil. Journal of Plant Pathology, Bari, v.92, n.2, p.285-302, 2010b.

BELASQUE JUNIOR, J.; YAMAMOTO, P.T.; MIRANDA, M.P.; BASSANEZI, R.B.; AYRES, A.J.; BOVÉ, J.M. Controle do Huanglongbing no estado de São Paulo, Brasil. Citrus Research \& Technology, Cordeirópolis, v.31, p.53-64, 2010c.

BERGAMIN FILHO, A.; INOUE-NAGATA, A.K.; BASSANEZI, R.B.; BELASQUE JR, J.; AMORIM, L.; MACEDO, M.A.; BARBOSA, J.C.; WILLOCQUET, L.; SAVARY, S. The importance of primary inoculum and area-wide disease management to crop health and food security. Food Security, Auzeville, v.8, n.1, p.221-238, 2016.

BLAUSTEIN, R.A.; LORCA, G.L.; TEPLITSKI, M. Challenges for managing Candidatus Liberibacter spp. (Huanglongbing disease pathogen): current control measures and future directions. Phytopathology, Saint Paul, v.108, p.424-435, 2018. 
BOINA, D.R.; MEYER, W.L.; ONAGBOLA, E.O.; STELINSKI, L.L. Quantifying dispersal of Diaphorina citri (Hemiptera: Psyllidae) by immunomarking and potential impact of unmanaged groves on commercial citrus management. Environmental Entomology, Oxford, v.38, p.1250-1258, 2009.

BOVÉ, J. M. Huanglongbing: A destructive, newlyemerging, century-old disease of citrus. Journal of Plant Pathology, Bari, v.88, n.1, p.7-37, 2006.

CIFUENTES-ARENAS, J.C.; GOES, A.; MIRANDA, M.P.; BEATTIE, G.A.C.; LOPES, S.A. Citrus flush shoot ontogeny modulates biotic potential of Diaphorina citri. PLoS One, San Francisco, v.13, n.1, e0190563, 2018.

COSTA, G.V.; NEVES, C.S.V.J.; TELLES, T.S. Spatial dynamics of orange production in the state of Paraná, Brazil. Revista Brasileira de Fruticultura, Jaboticabal, v.42, n.2, e-525, 2020.

DE CARLI, L.F.; MIRANDA, M.P.; VOLPE, H.X.L.; ZANARDI, O.Z.; VIZONI, M.C.; MARTINI, F.M.; LOPES, J.A.p.Leaf age affects the efficacy of insecticides to control Asian citrus psyllid, Diaphorina citri (Hemiptera: Liviidae). Journal of Applied Entomology, College Park, v.142, p.689-695, 2018.

GASPAROTO, M.C.G.; HAU, B.; BASSANEZI, R.B.; RODRIGUES, J.C.; AMORIM, L. Spatiotemporal dynamics of citrus huanglongbing spread: a case study. Plant Pathology, Oxford, v.67, p.1621-1628, 2018.

GOTTWALD, T.R. Current epidemiological understanding of citrus huanglongbing. Annual Review of Phytopathology, Palo Alto, v.48, p.119-139, 2010.

GOTTWALD, T.R.; DA GRAÇA, J.V.; BASSANEZI, R.B. Citrus Huanglongbing: The pathogen and its impact. Plant Health Progress, Saint Paul, v.8, p, 1-36, 2007.

HALL, D.G.; ALBRECHT, U.; BOWMAN, K.D. Transmission rates of ' $\mathrm{Ca}$. Liberibacter asiaticus' by Asian citrus psyllid are enhanced by the presence and developmental stage of citrus flush. Journal of Economic Entomology, Lanham, v.109, n.2, p.558-563, 2016.

IBGE - Instituto Brasileiro de Geografia e Estatística. Pesquisa Agrícola Municipal - PAM. Rio de Janeiro, 2020. Disponível em: https://sidra.ibge.gov.br. Acesso em: 27 fev. 2020.
LI, S.; WU, F.; DUAN, Y.; SINGERMAN, A.; GUAN, Z. Citrus greening: management strategies and their economic impact. HortScience, Alexandria, v.55, n.5, p.604-612, 2020.

MONZO, C.; STANSLY, P.A. Economic injury levels for Asian citrus psyllid control in process oranges from mature trees with high incidence of huanglongbing. PloS One, San Francisco, v.12, n.4, e0175333, 2017.

MUNIR, S.; HE, P.; WU, Y.; HE, P.; KHAN, S.; HUANG, M.; CUI, W.; HE, P.; HE, Y. Huanglongbing control: Perhaps the end of the beginning. Microbial Ecology, Basingstoke v.76, p.192-204, 2018.

NUNES, W.M.C.; SOUZA, E.B.; LEITE JUNIOR, R.P.; SALVADOR, C.A.; RINALDI, D.A.; CROCE FILHO, J.; PAIVA, P.G. Plano de ação para o controle de huanglongbing no Estado do Paraná, Brasil. Citrus Research \& Technology, Cordeirópolis, v.31, n.2, p.169177, 2010.

OLIVEIRA, J.M.C.; NASCIMENTO, A.S.; MIRANDA, S.H.G.; BARBOSA, C.J.; LARANJEIRAS, F.F. Estimativa dos impactos econômicos decorrentes de eventual introdução do Huanglongbing (HLB) no estado da Bahia. Revista Brasileira de Fruticultura, Jaboticabal, v.35, n.3, p.755-762, 2013.

SINGERMAN, A.; USECHE, p.Florida citrus growers' first impressions on genetically modified trees. AgBioForum, Columbia, v.20, n.1, p.67-83, 2017.

SÉTAMOU, M.; BARTELS, D.W. Living on the edges: spatial niche occupation of Asian citrus psyllid, Diaphorina citri Kuwayama (Hemiptera: Liviidae), in citrus groves. PLoS One, San Francisco, v.10, n.7, e0131917, 2015.

SPREEN, T.H.; BALDWIN, J.; FUTCH, S.H. An economic assessment of the impact of huanglongbing on citrus tree plantings in Florida. HortScience, Alexandria, v.49, n.8, p.1052-1055, 2014.

SPREEN, T.H.; ZANSLER, M.L. Economic analysis of incentives to plant citrus trees in Florida. HortTechnology, Alexandria, v.26, n.6, p.720-726, 2016. 
STANSLY, P.A.; AREVALO, H.A.; QURESHI, J.A.; JONES, M.M.; HENDRICKS, K.; ROBERTS, P.D.; ROKA, F.M. Vector control and foliar nutrition to maintain economic sustainability of bearing citrus in Florida groves affected by huanglongbing. Pest Management Science, London, v.70, n.3, p.415-426, 2014.

TANSEY, J.A.; VANACLOCHA, P.; MONZO, C.; JONES, M.; STANSLY, P.A.Costs and benefits of insecticide and foliar nutrient applications to huanglongbing-infected citrus trees. Pest Management Science, London, v.73, n.5, p.904-916, 2017.
TAZIMA, Z.H.; NEVES, C.S.V.J.; STENZEL, N.M.C.; YADA, I.F.U.; LEITE JUNIOR, R.p.Produção e qualidade de frutas de cultivares de laranja-doce no norte do Paraná. Revista Brasileira de Fruticultura, Jaboticabal, v.31, n.2, p.474-479, 2009.

TREJO-PECH, C.J.O.; SPREEN, T.H.; ZANSLER, M.L. Is Growing oranges in Florida a good investment?. American Journal of Agricultural Economics, Oxford, v.100, n.2, p.625-639, 2018. 